\title{
FAKTOR-FAKTOR PALING BERPENGARUH TERHADAP PENYEDIAAN PERUMAHAN DAN AKSESIBILITAS PEMBIAYAAN PERUMAHAN BAGI MASYARAKAT BERPENGHASILAN RENDAH
}

\section{Neysa Dianesdhika Jasrul, Ayomi Dita Rarasati}

Fakultas Teknik, Universitas Indonesia (UI) Depok Jawa Barat, Indonesia

Email: neysadj@gmail.com, ayomi@eng.ui.ac.id

\section{Abstrak}

Setiap negara memiliki tanggung jawab untuk memenuhi kebutuhan akan hunian yang berkualitas bagi masyarakat berpenghasilan rendah (MBR) dalam bentuk pelaksanaan program perumahan terjangkau. Meskipun program-program perumahan terjangkau marak diadakan di berbagai negara, terdapat beragam permasalahan yang dihadapi dalam pelaksanaannya. Di Indonesia sendiri, penyediaan perumahan dengan berbagai program bantuan pembiayaan yang ada tergolong belum terjangkau, terutama bagi MBR. Hal tersebut mendorong untuk dirancangnya strategi yang dapat meningkatkan penyediaan perumahan dan aksesibilitas pembiayaan perumahan bagi MBR. Guna merancang strategi yang tepat untuk meningkatkan penyediaan perumahan dan aksesibilitas pembiayaan perumahan bagi MBR, dibutuhkan analisis yang mendalam terlebih dahulu terhadap permasalahan yang tengah dihadapi dalam penyelenggaraan perumahan. Makalah ini menganalisis permasalahan-permasalahan penyelenggaraan perumahan dalam Program Sejuta Rumah sebagai program perumahan terjangkau di Indonesia guna mengidentifikasi faktor yang paling berpengaruh terhadap penyediaan perumahan dan aksesibilitas pembiayaan perumahan bagi MBR. Permasalahan-permasalahan penyelenggaraan perumahan dalam program perumahan terjangkau tersebut dianalisis menggunakan Interpretive Structural Modeling (ISM) untuk menentukan hubungan timbal balik antara permasalahanpermasalahan tersebut. Hasil analisis dari permasalahan-permasalahan tersebut pun berupa permasalahan yang paling berpengaruh terhadap permasalahan lainnya dalam penyelenggaraan perumahan, yang mana menjadi masukan untuk mengidentifikasi faktor yang paling berpengaruh terhadap penyediaan perumahan dan aksesibilitas pembiayaan perumahan bagi MBR. Makalah ini pun menyimpulkan bahwa faktor dukungan pemangku kepentingan, faktor bidang lahan, serta faktor regulasi mengenai perumahan dan kawasan permukiman merupakan faktor-faktor yang paling berpengaruh terhadap permasalahan penyelenggaraan perumahan dalam Program Sejuta Rumah sebagai program perumahan terjangkau di Indonesia.

Kata Kunci: penyediaan perumahan; pembiayaan perumahan; perumahan terjangkau; interpretive structural modeling

$\begin{array}{ll}\text { How to cite: } & \text { Jasrul. N.D \& Ayomi Dita Rarasati (2022) Faktor-Faktor Paling Berpengaruh Terhadap Penyediaan } \\ & \text { Perumahan dan Aksesibilitas Pembiayaan Perumahan Bagi Masyarakat Berpenghasilan Rendah. Syntax } \\ & \text { Literate: Jurnal Ilmiah Indonesia, 7(1). http://dx.doi.org/10.36418/ Syntax-Literate.v7i1.6059 } \\ & \text { 2548-1398 } \\ \text { E-ISSN: } & \text { Ridwan Institute }\end{array}$


Faktor-Faktor Paling Berpengaruh Terhadap Penyediaan Perumahan dan Aksesibilitas Pembiayaan Perumahan Bagi Masyarakat Berpenghasilan Rendah

\section{Abstract}

Every country has a responsibility to meet the need for quality housing for lowincome earners by implementing affordable housing programs. Although affordable housing programs are widely implemented in various countries, there are various problems faced within the implementation. In Indonesia, affordable housing provision with various existing financing assistance programs is classified as unaffordable, especially for low-income earners. This problem encourages the development of strategies that can increase housing provision and housing finance accessibility for low-income earners. In order to develop the right strategy to increase housing provision and housing finance accessibility for low-income households, an in-depth analysis of the problems that are currently faced within the implementation of housing is required to be conducted. In this paper, problems that are faced within the implementation of an affordable housing program in Indonesia called Program Sejuta Rumah are analyzed in order to identify the most influential factors towards housing provision and housing finance accessibility for lowincome earners. The problems faced within the implementation of that affordable housing program are analyzed using Interpretive Structural Modeling (ISM) to determine the interrelationships between the problems. The results of the analysis of the problems then became an input to identify the most influential factors towards housing provision and housing finance accessibility for low-income earners. This paper concludes that factors such as stakeholder support, factors regarding land, and regulation regarding housing and settlement areas are the most influential factors towards the problems that are faced in housing implementation within the affordable housing program.

Keywords: housing provision; housing finance; affordable housing; interpretive structural modeling

Received: 2021-12-20; Accepted: 2022-01-05; Published: 2022-01-15

\section{Pendahuluan}

Meskipun program-program perumahan terjangkau marak diadakan di berbagai negara oleh pemerintah, terdapat beragam permasalahan yang dihadapi dalam pelaksanaan program tersebut. Sebagai contoh, penelitian terkini menekankan pembahasan mengenai tren ketimpangan kekayaan perumahan atau housing wealth di Inggris dimana berupa peningkatan konsentrasi kekayaan perumahan bagi kelompok masyarakat yang memiliki kekayaan berupa perumahan dan pendapatan yang lebih tinggi (Arundel, 2017). Terdapat pula literatur yang membahas program perumahan yang malah menghasilkan peningkatan kesenjangan karena tersedianya skema pembiayaan perumahan yang tidak dirancang dengan baik (Chen, Wu, Liu, \& Wang, 2020). Di Indonesia sendiri, pembiayaan perumahan terjangkau dalam bentuk pinjaman kredit pemilikan rumah (KPR) belum berfungsi dengan baik khususnya bagi masyarakat berpenghasilan rendah (MBR) (Soeroto, 2018). Sehingga, bila membahas mengenai perumahan untuk MBR, permasalahan yang paling berkaitan erat adalah keterjangkauan perumahan. 
Berdasarkan Pasal 1 Ayat 3 Peraturan Menteri PUPR No. 12 Tahun 2020 "Penyelenggaraan Perumahan dan Kawasan Permukiman adalah kegiatan perencanaan, pembangunan, pemanfaatan, dan pengendalian termasuk di dalamnya pengembangan kelembagaan, pendanaan dan sistem pembiayaan, serta peran Masyarakat yang terkoordinasi dan terpadu". Adapun penyediaan perumahan (termasuk perencanaan, pembangunan, dan pengendalian) dan pembiayaan perumahan merupakan bagian dari penyelenggaraan perumahan. Berdasarkan rantai pasok penyediaan perumahan, penyediaan perumahan berkaitan dengan sisi pasokan perumahan, sedangkan pembiayaan perumahan berkaitan dengan sisi permintaan perumahan (Direktorat Jenderal Pembiayaan Perumahan, 2017). Adapun ketidakterjangkauan perumahan disebabkan oleh permasalahan kesenjangan antara sisi pasokan dan permintaan perumahan (Direktorat Jenderal Perumahan, 2020).

Kesenjangan tersebut mendorong untuk dirancangnya suatu strategi yang dapat meningkatkan keseimbangan pasokan dan permintaan perumahan, yang mana berkaitan dengan peningkatan penyediaan dan aksesibilitas pembiayaan perumahan bagi MBR. Adapun Program Sejuta Rumah sebagai program rumah terjangkau di Indonesia memiliki tujuan untuk menggerakkan para pemangku kepentingan di bidang perumahan guna memaksimalkan potensi mereka dalam mempercepat penyediaan perumahan bagi masyarakat terutama MBR yang memiliki kebutuhan akan hunian layak (Waluyo, D., Hidayat, N., Amin, N., Nuraini, R., Putra, R. M., \& Yansah, 2019). Peningkatan performa program tersebut pun sangat diperlukan guna meningkatkan penyediaan perumahan dan aksesibilitas pembiayaan perumahan bagi MBR. Guna merancang strategi yang tepat untuk meningkatkan penyediaan perumahan dan aksesibilitas pembiayaan perumahan bagi MBR dalam Program Sejuta Rumah pun pastinya dibutuhkan analisis yang mendalam terlebih dahulu terhadap permasalahan yang tengah dihadapi dalam program tersebut.

Berdasarkan penelitian terdahulu, berbagai permasalahan di bidang perumahan di berbagai daerah telah banyak dibahas dan dianalisis. Sebagai contoh, penelitian oleh (muflih Nasution, 2019) menganalisis permasalahan dalam beberapa perumahan di pinggiran Kota Medan yang menyimpulkan pentingnya peran pengembang dalam memperhatikan berbagai aspek dalam mendesain dan membangun perumahan yang layak dan ideal, serta pentingnya kesesuaian lokasi perumahan dengan Rencana Tata Ruang Wilayah (RTRW) yang telah diatur. Selain itu, (Wijaya \& Handrisal, 2021) menyimpulkan dalam penelitian mereka bahwa penyediaan perumahan bagi MBR di Kabupaten Lahat Provinsi Sumatera Selatan belum terlaksana dengan maksimal dikarenakan oleh permasalahan yang berupa belum optimalnya perizinan pembangunan perumahan bagi MBR (yang mana dihambat oleh kewenangan Pemerintah Pusat dan Pemerintah Daerah yang tumpang-tindih dalam Undang-Undang Nomor 1 Tahun 2011 tentang Perumahan dan Kawasan Permukiman dan Undang-Undang Nomor 23 Tahun 2014 tentang Pemerintahan Daerah yang berkaitan dengan bidang perumahan), sementara pada saat yang bersamaan daerah tersebut mengalami keterbatasan lahan untuk membangun rumah tapak. Sedangkan penelitian oleh (Margawati, 2021) 
menyimpulkan bahwa permasalahan perumahan di Kecamatan Mlati, Kabupaten Sleman, D. I. Yogyakarta antara lain berkaitan dengan permasalahan administratif dan teknis berupa adanya perumahan yang tidak memiliki izin, pengembangan perumahan yang dilaksanakan dengan metode pecah kavling, pembangunan perumahan yang tidak didasari oleh suatu site plan, serta prasarana dan sarana terbangun yang kurang memadai. Permasalahan perumahan juga dibahas dalam penelitian oleh (Putra, 2014), yang mana menekankan permasalahan peran Pemerintah Daerah yang kurang mendukung pelaksanaan penyediaan perumahan di Kecamatan Banyumanik Kota Semarang.

Penelitian-penelitian terdahulu cenderung lebih banyak membahas mengenai permasalahan perumahan pada daerah tertentu dibandingkan mengenai permasalahan penyelenggaraan perumahan di tingkat nasional secara keseluruhan. Adapun permasalahan penyelenggaraan perumahan yang sedang dihadapi di tingkat nasional secara keseluruhan berdasarkan sumber terkini perlu diteliti dalam upaya merancang strategi yang tepat untuk meningkatkan penyediaan perumahan dan aksesibilitas pembiayaan perumahan bagi MBR. Sehingga, permasalahan penyelenggaraan perumahan yang diidentifikasi dalam Rencana Strategis Direktorat Jenderal Perumahan, Kementerian Pekerjaan Umum dan Perumahan Rakyat (PUPR) periode jangka menengah 2020-2024, perlu dijadikan acuan dalam menganalisis permasalahan yang tengah dihadapi dalam penyelenggaraan perumahan pada Program Sejuta Rumah sebagai program perumahan terjangkau di Indonesia.

Penelitian ini ditujukan untuk menganalisis permasalahan yang sedang dihadapi dalam penyelenggaraan perumahan pada Program Sejuta Rumah untuk mengidentifikasi faktor-faktor paling berpengaruh terhadap penyediaan perumahan dan aksesibilitas pembiayaan perumahan bagi MBR dalam program perumahan terjangkau tersebut. Sehingga, dengan teridentifikasinya faktor-faktor paling berpengaruh dalam Program Sejuta Rumah, hal tersebut dapat menjadi masukan dalam merancang strategi yang tepat untuk memaksimalkan potensi para pemangku kepentingan program tersebut sebagai upaya meningkatkan penyediaan perumahan dan aksesibilitas pembiayaan perumahan khususnya bagi MBR.

\section{Metode Penelitian}

Metode penelitian yang digunakan untuk menganalisis permasalahan yang paling berpengaruh terhadap permasalahan lainnya dalam program perumahan terjangkau adalah berupa pengembangan model menggunakan Interpretive Structural Modeling (ISM), yang mana dapat dilaksanakan untuk memperoleh jenis korelasi antara permasalahan-permasalahan yang dianalisis. Data ISM dalam penelitian ini diperoleh berdasarkan wawancara dengan instrumen kuesioner terhadap 6 Pakar. Data tersebut pun berupa pendapat para Pakar tersebut mengenai jenis korelasi dari berbagai permasalahan penyelenggaraan perumahan dalam Program Sejuta Rumah sebagai program perumahan terjangkau di Indonesia. Pendapat para Pakar kemudian diolah melalui pengembangan model berbasis ISM. 
Pengembangan model berbasis ISM dimulai dengan memasukkan jenis korelasi dari berbagai permasalahan berdasarkan pendapat para Pakar tersebut ke dalam Structural Self-Interaction Matrix (SSIM) menggunakan simbol sesuai jenis keterkaitan yang terbagi kedalam empat kategori berupa simbol $\mathrm{V}$ ketika variabel atau faktor $\mathrm{i}$ mengarah ke faktor $\mathrm{j}$ tetapi faktor $\mathrm{j}$ tidak mengarah ke faktor $\mathrm{i}$, simbol A ketika faktor $\mathrm{j}$ mengarah ke faktor i tetapi faktor i tidak mengarah ke faktor $\mathrm{j}$, simbol $\mathrm{X}$ ketika faktor $\mathrm{i}$ mengarah ke faktor $\mathrm{j}$ dan faktor $\mathrm{j}$ juga mengarah ke faktor $\mathrm{i}$, dan simbol $\mathrm{O}$ Ketika hubungan antar faktor i dan faktor j tidak terlihat valid (Tan, Chen, Xue, \& Lu, 2019); (Sandbhor \& Botre, 2014). Adapun i melambangkan faktor atau variabel yang diilustrasikan dalam kolom paling kiri pada tabel SSIM, dan j melambangkan faktor atau variabel yang diilustrasikan dalam baris paling atas pada tabel SSIM.

SSIM yang dikembangkan kemudian ditransfer ke Reachability Matrix untuk keperluan analisis lebih lanjut dengan mengganti simbol-simbol V, A, X, dan O, dengan angka 1 atau 0 sesuai dengan petunjuk yang dijelaskan dalam penelitian oleh (Sandbhor \& Botre, 2014) yang dapat dijabarkan dalam Tabel 1.

\section{Tabel 1}

\begin{tabular}{|c|c|c|}
\multicolumn{3}{|c}{ Aturan transformasi SSIM ke Reachability Matrix } \\
\hline Kategori keterkaitan & Hubungan (i ke j) & Hubungan (j ke i) \\
\hline V & 1 & 0 \\
\hline A & 0 & 1 \\
\hline X & 1 & 1 \\
\hline O & 0 & 0 \\
\hline
\end{tabular}

Sumber: (Sandbhor \& Botre, 2014)

Reachability Matrix yang dikembangkan pun dapat mengilustrasikan nilai dari kemampuan mempengaruhi atau driving power serta nilai keterpengaruhan atau dependence dari variabel-variabel atau faktor-faktor yang dianalisis. Matriks reachability kemudian ditransformasikan menjadi diagram MICMAC atau Matrice d'Impacts Croises Multiplication Appliquee a un Classement, yang mana dapat membantu dalam mengklasifikasi faktor-faktor yang dianalisis yang diadopsi oleh peneliti terdahulu (Tan et al., 2019), dimana faktor-faktor tersebut dibagi menjadi empat kategori. Kategori-kategori tersebut antara lain berupa variabel autonomous (variabel yang memiliki kemampuan mempengaruhi atau driving power dan keterpengaruhan atau dependence rendah); variabel dependen (variabel yang memiliki driving power rendah tetapi dependence tinggi); variabel independen (variabel yang memiliki driving power tinggi tetapi dependence rendah); dan variabel linkage (variabel yang memiliki driving power dan dependence tinggi) berdasarkan literatur yang dikutip sebelumnya.

Sehingga, dengan dikembangkannya diagram MICMAC dalam pengembangan model berbasis ISM tersebut, dapat disimpulkan faktor yang paling berpengaruh 
terhadap permasalahan penyelenggaraan perumahan dalam Program Sejuta Rumah. Pakar-pakar yang dijadikan narasumber dalam penelitian ini pun merupakan orangorang yang memiliki keahlian serta pengetahuan dalam bidang perumahan. Pakar-pakar tersebut merupakan pemangku kepentingan di bidang perumahan dengan jabatan berupa Direktur, Kepala Sub Direktorat, atau Kepala Divisi dalam Kementerian atau Instansi yang bekerja sama dengan Kementerian.

\section{Hasil dan Pembahasan}

\section{A. Program Perumahan Terjangkau}

Program Perumahan Terjangkau adalah program yang telah menjadi agenda pemerintah di berbagai negara untuk meningkatkan kondisi hidup masyarakat berpenghasilan rendah (MBR) (Lin, Zhang, \& Geertman, 2015); (Gan et al., 2017). Sudah pasti menjadi tanggung jawab setiap negara untuk memenuhi kebutuhan akan hunian yang layak dan berkualitas bagi seluruh masyarakatnya. Sehingga, penyediaan perumahan bagi MBR dan masyarakat berpenghasilan tidak tetap pun merupakan tantangan yang perlu dikelola oleh pemerintah agar kelompok tersebut dapat memperoleh manfaat yang maksimal dari program perumahan terjangkau yang diselenggarakan pemerintah.

Adapun bagi MBR sebagai kelompok masyarakat yang sejauh ini belum dapat menerima manfaat dari program perumahan terjangkau secara maksimal, permasalahan yang mereka hadapi berupa keterjangkauan perumahan. Ketidakterjangkauan perumahan disebabkan oleh permasalahan penyediaan perumahan, yang mana berupa belum seimbangnya antara pasokan perumahan yang berkaitan dengan penyediaan perumahan, dengan permintaan perumahan yang berkaitan dengan pembiayaan perumahan (Direktorat Jenderal Perumahan, 2020). Sehingga, permasalahan program perumahan terjangkau yang perlu diteliti, perlu dikaitkan dengan permasalahan penyediaan yang berkaitan dengan sisi pasokan atau supply side perumahan serta permasalahan pembiayaan perumahan yang berkaitan dengan sisi permintaan atau demand side perumahan.

Program Sejuta Rumah sebagai program perumahan terjangkau di Indonesia merupakan program Kementerian PUPR yang dilaksanakan sejak tahun 2015 dengan tujuan menggerakkan pemangku kepentingan di bidang perumahan untuk menurunkan backlog (selisih antara kebutuhan dan ketersediaan perumahan) serta meningkatkan kualitas rumah tidak layak huni, yang mana sejauh ini merupakan tantangan dalam pelaksanaan program tersebut (Waluyo, D., Hidayat, N., Amin, N., Nuraini, R., Putra, R. M., \& Yansah, 2019). Realisasi penyediaan perumahan melalui program perumahan pemerintah pada 2016 hanya sekitar $6.5 \%$ dari total backlog, yang mana disebabkan oleh ketidakseimbangan antara realisasi penyediaan dan permintaan atau supply (berupa penyediaan lahan, pelaksanaan perizinan, penyediaan bahan bangunan, dan pembangunan perumahan) dan demand (berupa pembiayaan primer, penghunian, dan pembiayaan sekunder perumahan) perumahan (Direktorat Jenderal Pembiayaan Perumahan, 2017). Sedangkan, angka backlog 
bertambah seiring berjalannya waktu, yang mana dikarenakan oleh pertumbuhan penduduk (sekitar 1,3\% per tahun) dan tingkat urbanisasi yang tinggi, sekitar 4,1\%, per tahun (Direktorat Jenderal Pembiayaan Perumahan, 2017). Selain permasalahan backlog perumahan, permasalahan penyediaan perumahan lainnya juga berupa masih rendahnya persentase rumah layak huni di Indonesia yang sesuai dengan standar bangunan rumah layak dalam Sustainable Development Goals yang ditetapkan oleh Perserikatan Bangsa-Bangsa (PBB) dengan persentase 59,54\% rumah layak huni pada tahun 2020 berdasarkan Badan Pusat Statistik.

Permasalahan penyediaan perumahan lainnya berkaitan dengan kesenjangan antara ketersediaan dana dan kebutuhan, serta masih terbatasnya skema pembiayaan bagi MBR (Direktorat Jenderal Pembiayaan Perumahan, 2017). Sehingga, skema pembiayaan bagi MBR perlu dikembangkan untuk mengurangi kesenjangan realisasi dan kebutuhan perumahan.

Selain ketersediaan perumahan, aksesibilitas pembiayaan perumahan juga merupakan masalah yang perlu dianalisis. Angka rasio Kredit Pemilikan Rumah (KPR) terhadap Produk Domestik Bruto (PDB) di Indonesia rendah dibandingkan dengan rata-rata PDB negara berkembang lainnya (Direktorat Jenderal Pembiayaan Perumahan, 2017). Sebagai contoh, rasio KPR terhadap PDB di Indonesia berada dibawah beberapa negara berkempang yang merupakan negara tetangga seperti Filipina dan Thailand dengan angka 2.9\%. Namun, rasio tersebut juga dipengaruhi oleh fakta bahwa banyak masyarakat di Indonesia memiliki rumah bukan melalui KPR, melainkan dengan pendekatan rumah tumbuh, baik menggunakan KPR mikro atau dengan menabung bertahap. Berdasarkan data Rencana Strategis Direktorat Jenderal Perumahan tahun 2020-2024, 70\% rumah di Indonesia dibangun secara swadaya (Direktorat Jenderal Perumahan, 2020).

Adapun berdasarkan pengalaman internasional, lembaga keuangan bukan bank (LKBB) atau non-bank financial institution merupakan lembaga keuangan yang lebih cocok dalam menyalurkan KPR kepada MBR dibandingkan dengan bank karena memiliki keahlian yang lebih tinggi serta lebih mengenal karakter peserta KPR (Soeroto, 2018). LKBB yang memiliki pengalaman dan pengetahuan mengenai karakter MBR merupakan lembaga keuangan yang sesuai dalam menyalurkan produk pembiayaan perumahan yang paling cocok dengan profil MBR. Adapun skema pembiayaan perumahan sebagai bagian dari program perumahan terjangkau di Indonesia belum tersegmentasi dengan baik dan belum dapat dimanfaatkan oleh seluruh kelompok masyarakat secara maksimal, khususnya bagi MBR. Sehingga, skema pembiayaan perumahan yang dirancang dengan sesuai dengan profil MBR merupakan hal yang penting dalam upaya menyalurkan produk pembiayaan yang tepat serta dapat dimanfaatkan oleh kelompok masyarakat tersebut dengan maksimal.

Permasalahan ketersediaan perumahan dan aksesibilitas pembiayaan perumahan tersebut menimbulkan pertanyaan mengenai faktor-faktor apa saja yang dapat meningkatkan penyediaan dan aksesibilitas pembiayaan perumahan. 
Sehingga, dapat dirancang strategi yang tepat sebagai upaya meningkatkan penyediaan dan aksesibilitas pembiayaan perumahan terutama bagi MBR.

Guna merancang strategi yang tepat sebagai upaya meningkatkan penyediaan dan aksesibilitas pembiayaan perumahan terutama bagi MBR, perlu diidentifikasi terlebih dahulu permasalahan yang sedang dihadapi dalam penyelenggaraan perumahan program perumahan terjangkau. Berbagai permasalahan yang sedang dihadapi pemerintah dalam menyelenggarakan Program Sejuta Rumah pun perlu dianalisis guna menyimpulkan faktor yang paling berpengaruh terhadap permasalahan-permasalahn tersebut. Sehingga, dengan teridentifikasinya faktor yang paling berpengaruh terhadap permasalahan program perumahan terjangkau, hal tersebut dapat digunakan untuk merancang strategi untuk memaksimalkan potensi para pemangku kepentingan program tersebut sebagai upaya meningkatkan penyediaan perumahan dan aksesibilitas pembiayaan perumahan khususnya bagi MBR.

\section{B. Permasalahan dalam Program Perumahan Terjangkau}

Permasalahan-permasalahan yang akan dianalisis lebih lanjut dalam penelitian ini merupakan permasalahan pelaksanaan Program Sejuta Rumah yang mana berupa permasalahan penyelenggaraan perumahan terkini yang diidentifikasi dalam Rencana Strategis Direktorat Jenderal Perumahan Kementerian PUPR jangka menengah 2020-2024. Permasalahan penyelenggaraan perumahan telah mencakup permasalahan penyediaan serta pembiayaan perumahan, yang mana pada dasarnya merupakan permasalahan-permasalahan yang terintegrasi dan perlu dianalisis secara bersamaan guna mendapatkan strategi yang menyeluruh terhadap permasalahan di bidang perumahan. Berdasarkan Rencana Strategis Direktorat Jenderal Perumahan, Kementerian PUPR 2020-2024, permasalahan yang sedang dihadapi dalam penyelenggaraan perumahan mencakup berbagai aspek yang antara lain dapat dirangkum dalam Tabel 2.

Tabel 2

Permasalahan dalam Program Perumahan Terjangkau

\begin{tabular}{cl}
\hline \multicolumn{1}{c}{ Pariabel } \\
\hline (V1) & Permasalahan Bidang Lahan \\
\hline (V2) & Belum Maksimalnya Regulasi Mengenai PKP \\
\hline (V3) & Kebijakan Perizinan Belum Sepenuhnya Terlaksana \\
\hline (V4) & Belum Optimalnya Pembiayaan Perumahan \\
\hline (V5) & Basis data dan Ketersediaan Dokumen Perencanaan \\
\hline (V6) & Perbedaan Kewenangan Pemda Bidang Perumahan \\
\hline (V7) & Alokasi Anggaran TIdak Sesuai Target \\
\hline (V8) & Permasalahan Bidang Perumahan Bersifat Multi Sektoral dan Kompleks \\
\hline (V9) & Pemberdayaan Masyarakat yang Belum Optimal \\
\hline (V10) & Belum Efektifnya Pembentukan dan Peran Kelompok Kerja PKP \\
\hline
\end{tabular}

Sumber: PUPR, 2020 
Permasalahan Bidang Lahan dalam penyelenggaraan perumahan dalam program perumahan terjangkau berkaitan dengan keterbatasan lahan, terutama di kota besar di Indonesia yang tidak mendukung kebutuhan perumahan yang semakin meningkat (Kamim, Amal, \& Khandiq, 2019). Bahkan, di daerah padat penduduk seperti pada beberapa kecamatan di kota Depok, ketersediaan lahannya sudah tidak mampu menampung untuk perumahan (Budiarto, Dwiputri, \& Hambali, 2019).

Belum Maksimalnya Regulasi Mengenai Perumahan dan Kawasan Permukiman berkaitan dengan fakta bahwa peraturan yang berlaku saat ini belum dapat menjawab beberapa permasalahan pelaksanaan bidang perumahan di lapangan. Adapun berdasarkan penelitian oleh (Ebekozien, Abdul-Aziz, \& Jaafar, 2019) penyebab utama kesenjangan supply-demand perumahan terjangkau di Malaysia dari persepsi pengembang perumahan berupa kebijakan dan penegakan negara yang lemah, sistem pendaftaran yang longgar untuk masyarakat berpenghasilan rendah (MBR), biaya pembangunan dan konstruksi yang tinggi, serta isu seputar pembelian rumah.

Kebijakan Perizinan yang Belum Sepenuhnya Terlaksana berkaitan dengan masih sedikitnya Pemerintah Daerah yang teridentifikasi sudah menerbitkan Peraturan tentang kemudahan perizinan pembangunan perumahan berdasarkan Rencana Strategis Direktorat Jenderal Perumahan 2020-2024. Hal tersebut pastinya mempersulit pengembang sebagai pelaku pembangunan perumahan untuk membangun perumahan khususnya untuk MBR.

Belum Optimalnya Pembiayaan Perumahan berkaitan dengan belum tersegmentasinya produk pembiayaan perumahan dengan baik, sehingga program pembiayaan perumahan belum dapat menjangkau MBR dan masyarakat berpenghasilan tidak tetap dengan maksimal. Adapun berdasarkan penelitian oleh (Lestariningsih \& Basuki, 2016) Inflasi yang terkendali, kebijakan tingkat bunga yang rendah, dan pertumbuhan pendapatan perkapita dapat mendukung penyediaan perumahan bagi masyarakat.

Permasalahan basis data dan ketersediaan Dokumen Perencanaan berkaitan dengan belum andalnya basis data di tingkat nasional maupun daerah, serta belum dokumen perencanaan yang belum dilaksanakan secara keseluruhan khususnya di tingkat daerah. Penyediaan perumahan melibatkan berbagai pemangku kepentingan perumahan serta mencakup wilayah yang luas, sehingga perancangan sistem informasi manajemen basis data untuk memenuhi kebutuhan informasi bidang perumahan merupakan strategi yang perlu dilaksanakan (Rompas, 2020).

Perbedaan Kewenangan Pemda Bidang Perumahan berkaitan dengan peraturan berupa Undang-Undang No. 23 tahun 2014 yang menegaskan bahwa penyediaan perumahan merupakan kewenangan Pemerintah Pusat. Padahal peran Pemerintah Daerah sangat penting dalam penyediaan perumahan.

Permasalahan Alokasi Anggaran Tidak Sesuai Target berkaitan dengan sektor perumahan yang belum menjadi prioritas pembangunan. Pemerintah pusat sebagai 
stakeholder utama dalam merancang kebijakan memiliki kewajiban terkait dengan alokasi anggaran pembangunan perumahan (Setyaningrum, Sriyana, \& Purwanggono, 2019). Sehingga, untuk melaksanakan tujuan penyediaan perumahan dengan maksimal, pemerintah pusat sebaiknya lebih memperhatikan sektor perumahan.

Permasalahan Bidang Perumahan yang Bersifat Multisektor dan Kompleks berkaitan dengan banyaknya sektor yang terlibat dalam sektor perumahan, sehingga dukungan seluruh pemangku kepentingan yang terkait dalam program perumahan pun sangat penting dalam menghadapi seluruh permasalahan yang ada. Adapun berdasarkan tinjauan literatur, pendekatan manajemen pemangku kepentingan sangat penting untuk kesuksesan pelaksanaan berbagai projek, terutama proyek konstruksi (Xia, Zou, Griffin, Wang, \& Zhong, 2018). Sehingga, permasalahan yang berkaitan dengan pemangku kepentingan perlu dianalisis guna mengidentifikasi faktor yang paling berpengaruh terhadap program perumahan terjangkau perumahan.

Pemberdayaan Masyarakat yang Belum Optimal berkaitan dengan kurangnya kompetensi Tenaga Fasilitator Lapangan dalam pelaksanaan bantuan program perumahan. Lebih dari $70 \%$ rumah di Indonesia dibangun atas keswadayaan masyarakat (PUPR, 2020), namun tidak semua rumah yang dibangun tersebut sesuai dengan standar kelayakan hunian. Sehingga diperlukan pemberdayaan masyarakat yang dibantu oleh Tim Fasilitator Lapangan (TFL) di lapangan terkait penyelenggaraan perumahan swadaya (Direktorat Jenderal Perumahan, 2020); (Rahayu, 2019).

Sedangkan Belum Efektifnya Pembentukan dan Peran Kelompok Kerja Perumahan dan Kawasan Permukiman (Pokja PKP), yang mana merupakan badan yang mewadahi kolaborasi pemangku kepentingan di bidang perumahan, berkaitan dengan belum terbentuknya Pokja PKP di tingkat daerah secara keseluruhan, baik di tingkat Provinsi maupun di tingkat Kabupaten/Kota. Adapun bagi beberapa daerah yang telah membentuk Pokja PKP, perannya belum dapat terlaksana secara maksimal.

\section{Faktor yang Paling Berpengaruh dalam Permasalahan Program Perumahan Terjangkau}

Permasalahan-permasalahan penyelenggaraan perumahan dalam program perumahan terjangkau yang telah diidentifikasi sebelumnya pun ditentukan jenis korelasinya berdasarkan pendapat 6 Pakar dalam bidang perumahan. Hasil dari penentuan jenis keterkaitan variabel permasalahan-permasalahan tersebut pun dimasukkan ke dalam Structural Self-Interaction Matrix (SSIM) (Tan et al., 2019); (Sandbhor \& Botre, 2014) menggunakan simbol sesuai jenis keterkaitan yang terbagi kedalam empat kategori sebagai berikut:

$\mathrm{V}$ : Ketika faktor i mengarah ke faktor $\mathrm{j}$ tetapi faktor $\mathrm{j}$ tidak mengarah ke faktor $\mathrm{i}$

A: Ketika faktor $\mathrm{j}$ mengarah ke faktor $\mathrm{i}$ tetapi faktor $\mathrm{i}$ tidak mengarah ke faktor $\mathrm{j}$

$\mathrm{X}$ : Ketika faktor i mengarah ke faktor $\mathrm{j}$ dan faktor $\mathrm{j}$ juga mengarah ke faktor $\mathrm{i}$ 
O: Ketika hubungan antar faktor i dan faktor j tidak terlihat valid.

Adapun i melambangkan faktor atau variabel yang diilustrasikan dalam kolom paling kiri pada tabel SSIM, dan $\mathrm{j}$ melambangkan faktor atau variabel yang diilustrasikan dalam baris paling atas pada tabel SSIM. Berdasarkan pendapat Pakar-pakar yang telah diwawancara, SSIM pun diperoleh dan dapat diilustrasikan dalam Tabel 3.

Tabel 3

Structural Self-Interaction Matrix (SSIM)

\begin{tabular}{|c|c|c|c|c|c|c|c|c|c|c|}
\hline Variabel & V1 & $\mathrm{V2}$ & V3 & $\mathrm{V4}$ & V5 & V6 & V7 & V8 & V9 & V10 \\
\hline V1 & - & $X$ & $X$ & $X$ & $\mathrm{~A}$ & $\mathrm{~A}$ & $\mathrm{O}$ & $\mathrm{X}$ & $\mathrm{O}$ & $\mathrm{O}$ \\
\hline $\mathbf{V 2}$ & & - & $\mathrm{V}$ & $X$ & $X$ & $\mathrm{~V}$ & $\mathrm{X}$ & $X$ & $\mathrm{O}$ & A \\
\hline $\mathbf{V 3}$ & & & - & $\mathrm{V}$ & A & $\mathrm{A}$ & $\mathrm{O}$ & $\mathrm{X}$ & $\mathrm{O}$ & A \\
\hline $\mathrm{V4}$ & & & & - & $\mathrm{A}$ & $\mathrm{O}$ & $\mathrm{A}$ & $X$ & $X$ & $\mathrm{~A}$ \\
\hline V5 & & & & & - & $\mathrm{A}$ & $\mathrm{X}$ & $\mathrm{X}$ & $\mathrm{A}$ & A \\
\hline V6 & & & & & & - & $\mathrm{O}$ & $X$ & $\mathrm{~V}$ & $\mathrm{~V}$ \\
\hline V7 & & & & & & & - & $X$ & $\mathrm{O}$ & $X$ \\
\hline V8 & & & & & & & & - & $X$ & $\mathrm{X}$ \\
\hline V9 & & & & & & & & & - & $\mathrm{X}$ \\
\hline V10 & & & & & & & & & & - \\
\hline
\end{tabular}

Sumber: Olahan Penulis

SSIM yang dikembangkan kemudian ditransfer ke Reachability Matrix untuk analisis lebih lanjut dengan mengganti simbol-simbol V, A, X, dan O, dengan angka 1 dan 0 sesuai dengan petunjuk yang dijelaskan dalam penelitian oleh (Sandbhor \& Botre, 2014). Reachability Matrix dapat mengilustrasikan nilai dari kemampuan mempengaruhi atau driving power serta nilai keterpengaruhan atau dependence dari variabel-variabel yang dianalisis. Reachability Matrix yang diperoleh dalam penelitian ini pun dapat diilustrasikan dalam Tabel 4.

Tabel 4

Reachability Matrix

\begin{tabular}{cccccccccccc}
\hline Variabel & V1 & V2 & V3 & V4 & V5 & V6 & V7 & V8 & V9 & V10 & Driving Power \\
\hline V1 & 1 & 1 & 1 & 1 & 1 & 1 & 1 & 1 & 1 & 1 & 10 \\
\hline V2 & 1 & 1 & 1 & 1 & 1 & 1 & 1 & 1 & 1 & 1 & 10 \\
\hline V3 & 1 & 0 & 1 & 1 & 0 & 0 & 0 & 1 & 1 & 1 & 6 \\
\hline V4 & 1 & 1 & 0 & 1 & 0 & 0 & 0 & 1 & 1 & 1 & 6 \\
\hline V5 & 1 & 1 & 1 & 1 & 1 & 0 & 1 & 1 & 1 & 1 & 9 \\
\hline V6 & 1 & 0 & 1 & 0 & 1 & 1 & 0 & 1 & 1 & 1 & 7 \\
\hline V7 & 0 & 1 & 0 & 1 & 1 & 0 & 1 & 1 & 1 & 1 & 7 \\
\hline V8 & 1 & 1 & 1 & 1 & 1 & 1 & 1 & 1 & 1 & 1 & 10 \\
\hline V9 & 0 & 0 & 0 & 1 & 1 & 0 & 0 & 1 & 1 & 1 & 5 \\
\hline V10 & 0 & 1 & 1 & 1 & 1 & 0 & 1 & 1 & 1 & 1 & 8 \\
\hline Dependence & 7 & 7 & 7 & 9 & 8 & 4 & 6 & 10 & 10 & 10 \\
\hline \multicolumn{7}{c}{ Sumber: Olahan Penulis } \\
\hline
\end{tabular}


Reachability matrix kemudian transformasikan menjadi diagram MICMAC, yang mana dapat membantu dalam mengklasifikasi variabel-variabel atau faktorfaktor yang dianalisis yang diadopsi oleh peneliti terdahulu (Tan et al., 2019), dimana faktor-faktor tersebut dibagi menjadi empat kategori, yang antara lain berupa:

a. variabel autonomous, yaitu variabel yang memiliki kemampuan mempengaruhi atau driving power dan keterpengaruhan atau dependence rendah;

b. variabel dependen, yaitu variabel yang memiliki driving power rendah tetapi dependence tinggi;

c. variabel independen, yaitu variabel yang memiliki driving power tinggi tetapi dependence rendah;

d. dan variabel linkage, yaitu variabel yang memiliki driving power dan dependence tinggi.

Hasil Analisis Variabel dalam diagram MICMAC, yang mana merupakan diagram yang menunjukkan driving power dan dependence dari variabel-variabel yang dianalisis, dapat diilustrasikan dalam Gambar 1.

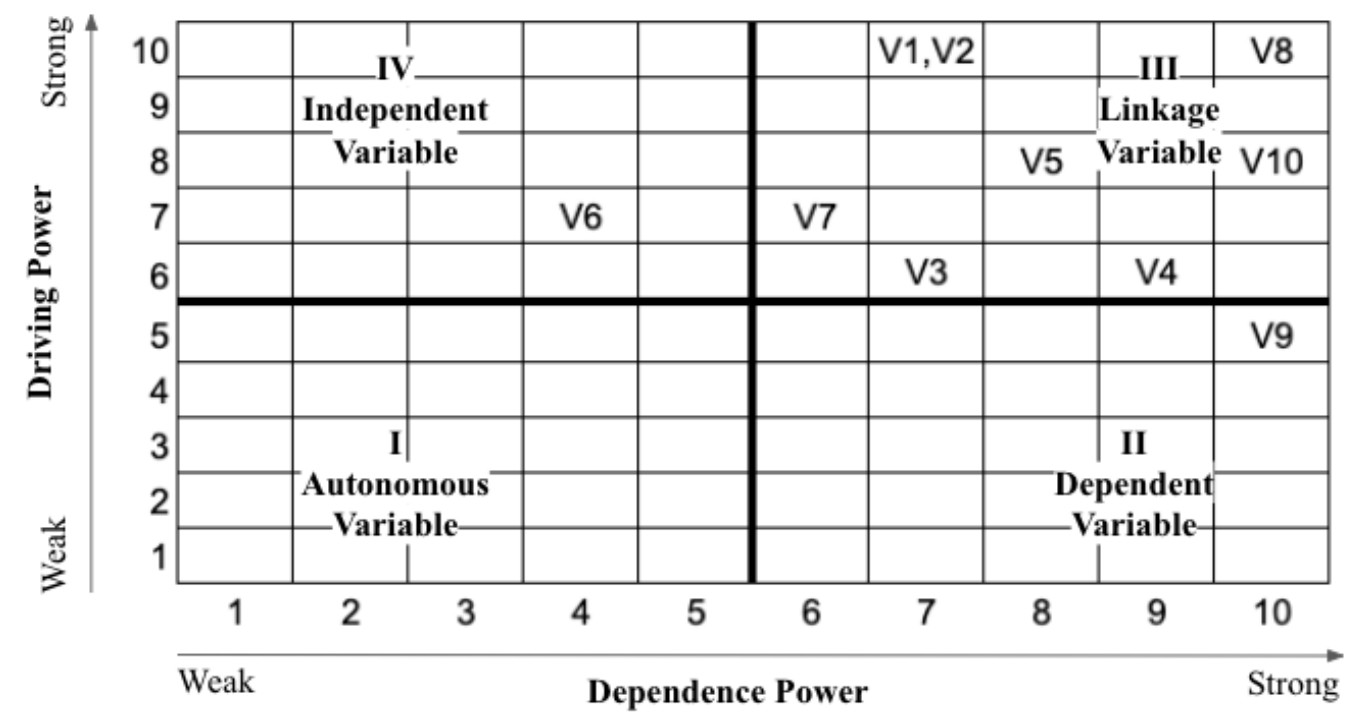

Gambar 1

Hasil Analisis Variabel dalam Diagram MICMAC

Sumber: Olahan Penulis

Berdasarkan pelaksanaan metode ISM dengan data yang telah didapat berdasarkan pendapat 6 Pakar dalam bidang perumahan, disimpulkan bahwa permasalahan yang paling berpengaruh dalam program perumahan terjangkau adalah berupa Permasalahan Bidang Perumahan yang Bersifat Multisektor dan Kompleks. Sehingga, faktor berupa dukungan seluruh pemangku kepentingan yang terlibat dalam program perumahan merupakan salah satu faktor yang paling mempengaruhi permasalahan program perumahan terjangkau. Permasalahan Bidang 
Perumahan yang Bersifat Multisektor dan Kompleks memiliki nilai driving power dan dependence yang paling tinggi berdasarkan ISM. Berdasarkan metode ISM yang telah dilaksanakan, Permasalahan Bidang Perumahan yang Bersifat Multisektor dan Kompleks memiliki nilai driving power 10 dan nilai dependence 10 dan tergolong pada kuadran linkage pada diagram MICMAC. Hal tersebut menunjukkan bahwa variabel permasalahan tersebut termasuk sebagai variabel yang bersifat tidak stabil dan setiap tindakan yang dilakukan terhadap variabel tersebut memiliki efek pada variabel lainnya serta variabel itu sendiri, sehingga pemangku kepentingan program harus berhati-hati dalam mengelola variabel-variabel yang termasuk dalam kuadran linkage (Sandbhor \& Botre, 2014).

Selain itu, permasalahan yang memiliki driving power yang sama berdasarkan hasil ISM berupa Permasalahan Bidang Lahan dan Belum Maksimalnya Regulasi Mengenai Perumahan dan Kawasan Permukiman, yang mana keduanya memiliki nilai driving power 10 dan nilai dependence 7 . Kedua permasalahan tersebut juga termasuk dalam kuadran linkage pada diagram MICMAC. Sehingga, berdasarkan tingginya driving power dari permasalahan-permasalahan tersebut, faktor bidang lahan dan faktor regulasi mengenai perumahan dan kawasan permukiman juga merupakan faktor yang paling mempengaruhi permasalahan dalam program perumahan terjangkau selain faktor dukungan pemangku kepentingan. Sehingga, dapat disimpulkan pula bahwa faktor-faktor tersebut merupakan faktor-faktor yang paling berpengaruh terhadap penyediaan dan aksesibilitas pembiayaan perumahan bagi MBR.

Adapun berbagai permasalahan lainnya seperti Kebijakan Perizinan Belum Sepenuhnya Terlaksana (V3), Belum Optimalnya Pembiayaan Perumahan (V4), Basis Data dan Ketersediaan Dokumen Perencanaan (V5), Alokasi Anggaran Tidak Sesuai Target (V7), dan Belum Efektifnya Pembentukan dan Peran Kelompok Kerja (V10) juga termasuk pada kuadran linkage pada diagram MICMAC, yang mana berarti variable permasalahan tersebut juga termasuk sebagai variabel yang bersifat tidak stabil dan pemangku kepentingan program harus berhati-hati dalam mengelola variabel-variabel ini.

Permasalahan berupa Perbedaan Kewenangan Pemda Bidang Perumahan (V6) merupakan bagian dari kuadran variabel independen, yang mana merupakan variabel dengan driving power tinggi, tetapi memiliki dependence rendah. Sehingga permasalahan tersebut memiliki pengaruh cukup tinggi terhadap permasalahan lainnya meskipun tidak begitu terpengaruh oleh permasalahan lainnya. Sedangkan, permasalahan berupa Pemberdayaan Masyarakat yang Belum Optimal (V9) merupakan bagian dari kuadran variabel dependen yang mana merupakan variabel dengan driving power rendah, tetapi memiliki dependence tinggi. Sehingga meskipun permasalahan tersebut tidak memiliki tingkat pengaruh yang tinggi terhadap permasalahan lainnya, permasalahan Pemberdayaan Masyarakat yang Belum Optimal memiliki tingkat keterpengaruhan yang tinggi terhadap permasalahan lainnya. 


\section{Kesimpulan}

Faktor berupa dukungan pemangku kepentingan, faktor bidang lahan dan faktor regulasi mengenai perumahan dan Kawasan permukiman merupakan faktor yang paling mempengaruhi permasalahan dalam program perumahan terjangkau berdasarkan pendapat 6 Pakar yang merupakan pemangku kepentingan bidang perumahan yang telah dianalisis menggunakan ISM. Sehingga, dapat disimpulkan pula bahwa faktor-faktor tersebut merupakan faktor-faktor yang paling berpengaruh terhadap penyediaan dan aksesibilitas pembiayaan perumahan bagi MBR. Berdasarkan faktor-faktor paling berpengaruh tersebut, strategi sebagai upaya untuk meningkatkan penyediaan dan pembiayaan perumahan bagi MBR pun dapat dirancang yang terfokus pada faktor program perumahan terjangkau yang paling berpengaruh pada permasalahan program perumahan terjangkau. 


\section{BIBLIOGRAFI}

Arundel, R. (2017). Equity inequity: Housing wealth inequality, inter and intragenerational divergences, and the rise of private landlordism. Housing, Theory and Society, 34(2), 176-200. Google Scholar

Budiarto, A., Dwiputri, M., \& Hambali, R. (2019). Analisis Ketersediaan Dan Kebutuhan Lahan Perumahan Di Pusat Pelayanan Kota (PPK) Kota Depok (Studi Kasus: Kecamatan Pancoran Mas Dan Kecamatan Sukmajaya). Lakar: Jurnal Arsitektur, 1(1), 21-26. Google Scholar

Chen, M., Wu, Y., Liu, G., \& Wang, X. (2020). The effect of the housing provident fund on housing consumption and inequity risks. Cities, 104, 102812. Google Scholar

Direktorat Jenderal Pembiayaan Perumahan. (2017). Roadmap Sistem Pembiayaan Perumahan Indonesia. Direktorat Jenderal Pembiayaan Perumahan.

Direktorat Jenderal Perumahan. (2020). Rencana Strategis Direktorat Jenderal Perumahan 2020-2024. Direktorat Jenderal Perumahan.

Ebekozien, A., Abdul-Aziz, A.-R., \& Jaafar, M. (2019). Housing finance inaccessibility for low-income earners in Malaysia: Factors and solutions. Habitat International, 87, 27-35. Google Scholar

Gan, X., Zuo, J., Wu, P., Wang, J., Chang, R., \& Wen, T. (2017). How affordable housing becomes more sustainable? A stakeholder study. Journal of Cleaner Production, 162, 427-437. Google Scholar

Kamim, A. B. M., Amal, I., \& Khandiq, M. R. (2019). Problematika Perumahan Perkotaan di Kota Yogyakarta. Jurnal Sosiologi USK (Media Pemikiran \& Aplikasi), 13(1), 34-54. Google Scholar

Lestariningsih, D. W. I. J., \& Basuki, B. (2016). Kajian Kebijakan Pemerintah Terhadap Harga Properti Perumahan Di Perkotaan. Teodolita (Media Komunikasi Ilmiah Di Bidang Teknik), 16(1). Google Scholar

Lin, Y., Zhang, X., \& Geertman, S. (2015). Toward smart governance and social sustainability for Chinese migrant communities. Journal of Cleaner Production, 107, 389-399. Google Scholar

Margawati, T. (2021). Permasalahan Perumahan Di Pinggiran Kota Dan Faktor Yang Mempengaruhinya. Sekolah Tinggi Pertanahan Nasional. Google Scholar

Muflih Nasution, A. (2019). Analisis Permasalahan Perumahan dan Permukiman di Kota Medan. JAUR (Journal Of Architecture And Urbanism Research), 3(1), 2746. Google Scholar

Putra, A. S. (2014). Perencanaan Perumahan Bagi Masyarakat Berpenghasilan Rendah 
Faktor-Faktor Paling Berpengaruh Terhadap Penyediaan Perumahan dan Aksesibilitas Pembiayaan Perumahan Bagi Masyarakat Berpenghasilan Rendah

di Kecamatan Banyumanikkota Semarang. Teknik PWK (Perencanaan Wilayah Kota), 3(4), 719-728. Google Scholar

Rahayu, S. B. (2019). Implementasi Program Bantuan Stimulan Perumahan Swadaya (BSPS) Di Jawa Timur. Jurnal Ekonomi Dan Manajemen, 20(3), 25-44. Google Scholar

Rompas, L. M. (2020). Perancangan Sistem Informasi Manajemen Data Base Perumahan Kecamatan Mapanget Kota Manado. TEKNO, 18(74). Google Scholar

Sandbhor, S., \& Botre, R. (2014). Applying total interpretive structural modeling to study factors affecting construction labour productivity. Australasian Journal of Construction Economics and Building, The, 14(1), 20-31. Google Scholar

Setyaningrum, M. H., Sriyana, S., \& Purwanggono, B. (2019). Analisa Faktor Yang Berpengaruh Terhadap Keberhasilan Penyediaan Rumah Khusus. Rekayasa, 12(2), 126-134. Google Scholar

Soeroto, E. (2018). Efisiensi Sebagai Basis Kebijakan Penyelenggaraan Perumahan Rakyat. Bina Ekonomi, 22(1), 85-94. Google Scholar

Tan, T., Chen, K., Xue, F., \& Lu, W. (2019). Barriers to Building Information Modeling (BIM) implementation in China's prefabricated construction: An interpretive structural modeling (ISM) approach. Journal of Cleaner Production, 219, 949959. Google Scholar

Waluyo, D., Hidayat, N., Amin, N., Nuraini, R., Putra, R. M., \& Yansah, A. W. (2019). Perjalanan lima tahun program sejuta rumah (D. A. Soeranto \& D. Rukmana, Eds.). Yayasan Badan Penerbit Pekerjaan Umum.

Wijaya, M., \& Handrisal, H. (2021). Kebijakan Penyelenggaraan Perumahan Masyarakat Berpenghasilan Rendah di Kabupaten Lahat Provinsi Sumatera Selatan. KEMUDI: Jurnal Ilmu Pemerintahan, 6(01), 37-51. Google Scholar

Xia, N., Zou, P. X. W., Griffin, M. A., Wang, X., \& Zhong, R. (2018). Towards integrating construction risk management and stakeholder management: A systematic literature review and future research agendas. International Journal of Project Management, 36(5), 701-715. Google Scholar

\section{Copyright holder:}

Neysa Dianesdhika Jasrul, Ayomi Dita Rarasati (2022)

First publication right:

Syntax Literate: Jurnal Ilmiah Indonesia

This article is licensed under:

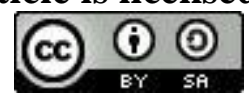

